\title{
Casamento em performance, parentesco em questão: gênero e sexualidade no São João de Belém, Pará*
}

\author{
Rafael da Silva Noleto**
}

\begin{abstract}
Resumo
Conectando dramas sociais e estéticos, as quadrilhas juninas encenam a resolução de um drama social de atribuição de paternidade. Um casamento surge como ação reparadora do drama instaurado, inserindo mulheres e homens em um sistema de relações de parentesco. Entretanto, nos concursos de quadrilha de Belém (Pará), há uma expressiva participação de homossexuais, travestis, transexuais e transgêneros, que desestabilizam, no plano estético, a divisão coreográfica binária entre damas e cavalheiros e, no plano simbólico/social, as concepções tradicionais sobre conjugalidade heterossexual.

Palavras-chave: Festas Juninas; Marcadores Sociais da Diferença;

Drama Social; Antropologia da Performance;

Parentesco.
\end{abstract}

Recebido em 23 de junho de 2016, aceito em 23 de março de 2017. Agradeço a Luiza Ferreira Lima, antropóloga e amiga querida, pela indicação de leitura do trabalho de Anne Finn Enke (citado nas páginas a seguir).

** Professor de Antropologia na Universidade Federal do Tocantins (UFT); coordenador do Grupo de Pesquisa em Gênero, Etnicidade e Sexualidade em Contextos Interétnicos (GESCI/UFT). rafaeldasilvanoleto@gmail.com 
Marriage in Performance, Kinship in Question: Gender and Sexuality in Belém's (Pará) São João

\begin{abstract}
Connecting social and aesthetic dramas, the June quadrilhas perform the resolution of a social drama about paternity assignment. A marriage emerges as reparative action of established drama, inserting women and men in a system of kinship relations. However, in Belém's (Pará) quadrilha contests there is a significant participation of homosexuals, travestis, transsexuals and transgenders, destabilizing, on the aesthetic level, the binary choreographic division between damas (ladies) and cavalheiros (gentlemen), and, at the symbolic/social level, traditional conceptions of heterosexual conjugality.
\end{abstract}

Keywords: June Festivals; Social Markers of Difference; Social Drama; Anthropology of Performance; Kinship. 


\section{Dança, gênero e sexualidade: uma introdução}

A primeira e mais nítida distinção que se sobressai quando se tem uma experiência com qualquer prática em dança diz respeito à divisão binária dos gêneros. ${ }^{1}$ De modo geral, a dança, com seus códigos de movimento todos ordenados para uma finalidade estética, ritual ou de busca pessoal pelo hedonismo, é inteiramente regulada para produzir diferenças que dizem respeito à retórica do gênero. Nesses termos, considero, concordando com Alexeyeff, que a

dança é uma arena na qual ideias corporificadas sobre
gênero são obviamente reproduzidas" de tal modo que "os
movimentos de dança, técnicas, coreografias, figurinos e

${ }^{1}$ Há uma vasta bibliografia que trata das conexões entre dança e gênero. Nem todos/as os/as autores/as que abordaram a temática possuem, necessariamente, uma intimidade com a linguagem $e$ as discussões empreendidas no campo dos estudos de gênero e sexualidade. No entanto, ainda que realizem certa confusão entre as definições de "sexo" e "gênero", autores como Hugo Zemp (2013: 39) destacam que "a diferença fisiológica dos sexos é universalmente interpretada por atribuições de papéis sociais específicos. Segundo as culturas, certos gêneros musicais e certos instrumentos de música são reservados aos homens, outros às mulheres, outros ainda podendo ser praticados pelos dois sexos. O mesmo acontece com a dança". No entanto, autoras como Kalissa Alexeyeff (2009), cujo trabalho está ancorado tanto no campo da antropologia da dança quanto no campo dos estudos de gênero e sexualidade, sofisticam a discussão no sentido de identificar processos de construção dos gêneros "feminino" e "masculino" em contextos nos quais a dança é um forte elemento socializador dos sujeitos. Em texto pouco conhecido, publicado no formato de artigo e com algumas considerações sobre uma dança Azande, Evans-Pritchard (2014:29) já havia assinalado, de modo mais etnográfico do que conceitual, que a dança apresenta funções coreográficas específicas para homens e para mulheres. Obviamente, o autor não utiliza a categoria "gênero" (que nem existia no jargão antropológico do modo como a utilizamos contemporaneamente), mas identifica papéis coreográficos que definem os contornos sociais de atuações performáticas consideradas como "masculinas" ou "femininas". Além disso, Evans-Pritchard (2014:33) ainda assinala aspectos relativos à dimensão da sexualidade ao afirmar que "a dança é um desses ambientes culturais em que a exibição sexual ocorre e em que a escolha é encorajada". 
canções todos apresentam noções normativas de feminilidade e masculinidade (Alexeyeff, 2009:17). ${ }^{2}$

Assim, a dança "constitui um vetor poderoso de identidade étnica, sexual, etária, hierárquica social" (Zemp, 2013:31). Por um lado, se a experiência com a dança for contemplativa, o espectador terá a oportunidade de observar a dinâmica coreográfica que codifica os gêneros a partir de movimentos corporais que os caracterizam no contexto estético de um determinado tipo de dança. Por outro lado, se a experiência com a dança for performática, o agente que dança, muito provavelmente, sentirá em seus próprios movimentos o peso do gênero inscrito em seu corpo, materializado coreograficamente. Se, nessa perspectiva mais ampla, pode-se dizer que a dança é generificada, falar mais especificamente sobre quadrilhas juninas é, sem dúvida, tratar de experiências corporais com o gênero.

Para além do gênero, os corpos que dançam denunciam o lugar social dos sujeitos, pois são também atravessados por elementos que os caracterizam em termos de raça, classe social, geração e sexualidade. ${ }^{3}$ Com relação a este último marcador social da diferença, tendo a concordar com a ideia de que 2 Todos os excertos do livro de Alexeyeff (2009) foram livremente traduzidos por
mim.

3 Trabalho a perspectiva de marcadores sociais da diferença a partir de uma vasta literatura que, nos últimos anos, vem problematizando a articulação entre classe social, gênero, geração, raça e sexualidade na produção de hierarquias entre sujeitos sociais. Ver Bederman (1996), Brah (2006), McClintock (2010), Stolke (2006), Moutinho (2004a; 2004b; 2006) e Piscitelli (2008). Devido ao escopo deste artigo, não abordarei detalhadamente uma discussão em torno desses marcadores sociais e seus mecanismos de produção da diferença mobilizados na vida social e política dos sujeitos. É necessário salientar que, para além de estratificar socialmente os sujeitos políticos, tais marcadores sociais também operam de modo articulado em amplos e complexos processos históricos responsáveis por construir imagens magnificadas de nação para certos grupos sociais politicamente organizados, transformando-os em comunidades sexualizadas. Para esse debate, ver Noleto (2015). 
a sexualidade é a própria substância da dança. Os en dehors, as elevações e aberturas do balé - sem falar nas dobras do tutu da bailarina, que lembram vulvas - são sexuais. E o balé está longe de ser excepcional em relação a outras danças. As ligações entre o sexo, o prazer visual, o movimento do corpo e a representação artística são óbvias (Schechner, 2013:47).

Este texto parte, então, de um estranhamento: se as festas juninas e os concursos de quadrilha reificam, nitidamente, uma divisão binária dos gêneros e pressupõem uma heterossexualidade e cisgeneridade coreográfica, como pensar na inserção de sujeitos homossexuais, travestis e transexuais nesse contexto de cultura popular? ${ }^{4}$ Este artigo trata dos concursos de quadrilha em Belém, interpretando-os como performances boas para pensar sobre a

${ }^{4}$ Creio ser necessário problematizar o uso da categoria cisgênero. Anne Finn Enke (2012) historiciza o uso desse termo destacando seu surgimento como um neologismo criado (no âmbito da biologia) por Dana Leland Defosse $e$ assinalando o trânsito polissêmico dessa categoria entre os contextos da academia e dos movimentos sociais LGBT. Por um lado, o termo "cisgênero" serve para evidenciar uma categoria de análise que, de certo modo, desnaturaliza a condição hegemônica de convergência entre o sexo biologicamente atribuído $e$ a identidade de gênero socialmente vivenciada. Dessa maneira, o uso dessa categoria causa um efeito de estranhamento, pois os sujeitos considerados "cisgênero" não estão habituados a pensarem sobre si próprios a partir de uma categoria de análise que os retire do patamar da norma. Esse efeito de estranhamento acaba por demonstrar que a cisgeneridade é apenas uma das possibilidades de experiência social com a identidade de gênero em interface com o sexo biológico. Por outro lado, Enke chama a atenção para a armadilha contida no uso dessa categoria, tendo em vista que "cisgênero" é também um termo que causa o efeito oposto de naturalizar, essencializar e estabilizar as categorias "mulher" e "homem". Em sua crítica, Enke assinala que "justamente quando a teoria queer e trans nos lembra que sexo e gênero são construídos $e$ não têm estabilidade a priori ("não se nasce uma mulher"), o termo cisgênero chega para afirmar não só que é possível para alguém permanecer "uma mulher", mas também que, afinal, esse alguém "nasce mulher" (Enke, 2012:63, livre tradução minha). No caso de minha pesquisa, utilizo o termo "cisgênero" como forma de interpelar a suposta naturalidade de uma categoria de sujeitos que, em geral, se percebe como autoevidente e que não é desnaturalizada em sua condição de norma. 
emergência e o protagonismo de sujeitos políticos ${ }^{5}$, marcados por elementos de gênero e sexualidade, que colocam em movimento um contexto de produção de cultura popular. ${ }^{6}$

${ }^{5}$ Utilizo a categoria "sujeitos políticos" no sentido que Sérgio Carrara (2010) a emprega, isto é, para designar agentes sociais que emergem na cena política como sujeitos de direitos, reivindicando políticas públicas voltadas ao combate a todas as formas de opressão de populações estigmatizadas por suas identidades sexuais e/ou de gênero. Para saber mais sobre categorias identitárias forjadas no surgimento de um movimento homossexual e (posteriormente) LGBT no Brasil, ler Regina Facchini (2009), Júlio Simões e Regina Facchini (2009) e James Green (2000).

6 Não tenho a intenção de discutir neste texto os conceitos de "tradição", "modernidade" ou "cultura popular". Considero que essa discussão já está consolidada de maneira consensual no sentido de reconhecer as dinâmicas de transformação das culturas em geral. Assim, as culturas ditas "populares" são também dinâmicas, constituindo-se como locus privilegiado para que sejam problematizados amplos processos de negociação entre os conceitos normativos de "tradição" e "modernidade". Sobre esses processos dinâmicos de transformação das culturas populares, indico a leitura do trabalho de Peter Burke (2010), no qual o autor reflete sobre a capacidade de agência dos sujeitos sociais nos processos de reinvenção das culturas populares. Para Burke, as mudanças nas culturas populares são propostas e realizadas por grupos e/ou sujeitos específicos que lidam diretamente com a feitura artística dos gêneros expressivos que as integram. No entanto, tais inovações são legitimadas pela comunidade, que demonstra seu poder de sanção aprovando ou reprovando as mudanças em curso. A proposta aqui é, justamente, ratificar esse caráter dinâmico das culturas populares, destacando como essas transformações ocorrem no âmbito das quadrilhas juninas a partir de problemáticas vinculadas às relações de gênero $e$ sexualidade. Há uma vasta literatura em Ciências Humanas que problematiza as "culturas" e suas "tradições" como entidades criadas socialmente em contextos históricos e políticos específicos. Essa bibliografia opera com a noção de que as "tradições" são produzidas de modo político, servindo, inclusive, para criar nacionalismos e forjar identidades culturais. As abordagens são diversas e, devido ao escopo deste artigo, não as discutirei em detalhes. Recomendo a leitura de Eric Hobsbawm e Terence Ranger (2012) e Anderson (2008). No âmbito antropológico, no qual a discussão gira em torno dos mecanismos conceituais por meio dos quais os antropólogos formulam o conceito de "cultura" e reconstroem as "tradições" e a "realidade" do contexto etnográfico, sugiro a leitura de Roy Wagner (2012) e Manuela Carneiro da Cunha (2009). Para uma discussão sobre processos de negociação entre elementos de "tradição" e "modernidade" no âmbito das festas juninas, recomendo a leitura dos trabalhos de Hugo Menezes Neto $(2008 ; 2015)$. 
Deve-se considerar que, em Belém, as festas juninas possuem um lugar de destaque na vida social, colorindo, anualmente, a paisagem urbana durante os meses de maio, junho $e$ até, como é mais raro, o início de julho. Em maio, iniciam-se os concursos de sujo ou concursos de ensaio, eventos nos quais os quadrilheiros apresentam, de modo inacabado, uma prévia do que serão suas apresentações nos concursos oficiais promovidos pelos governos locais. Em junho, mês em que efetivamente as festas juninas são celebradas, ocorrem os concursos de quadrilhas, que são pulverizados por diversas partes da cidade. Esses concursos dividem-se, basicamente, em dois grupos: os concursos juninos realizados em diversos bairros "periféricos" da cidade e, por fim, os certames oficiais promovidos pela Prefeitura Municipal de Belém e pelo Governo do Estado do Pará. Em âmbito municipal, os concursos são promovidos e gestados pela Fundação Cultural do Município de Belém (FUMBEL). No contexto estadual, os certames são promovidos pela Fundação Cultural do Pará (FCP) também denominada pelos quadrilheiros como Centur, em referência à antiga denominação de Centro Cultural e Turístico Tancredo Neves, nome dessa fundação cultural quando foi criada na década de 1980.

O período dessas festividades é popularmente chamado como quadra junina e essa denominação faz referência às quatro semanas do mês de junho em que os folguedos ocorrem, aos quatro santos católicos festejados na época (Santo Antônio, São João, São Pedro e São $\mathrm{Marçal}^{7}$ ) e, de algum modo, aos espaços onde grupos juninos se apresentam ao seu público, em geral, nas quadras, ginásios ou praças disponíveis em áreas de lazer da

\footnotetext{
7 A devoção a São Marçal não é encontrada em Belém, mas em São Luís (MA). De todo modo, creio ser importante frisar a existência de quatro santos juninos que conformam um ciclo de festividades religiosas. Pelos intercâmbios culturais entre Pará e Maranhão, materializados pelo compartilhamento de diversas modalidades de festas de Boi-bumbá (Pará) e Bumba-meu-boi (Maranhão), abre-se a possibilidade de influências culturais mútuas entre os dois estados, o que permite pensar que o termo "quadra" pode fazer referência também aos quatro santos celebrados no mês de junho.
} 
cidade. É um período em que os bairros "periféricos" de Belém (de onde emergem grande parte das quadrilhas juninas) se encontram no tempo e no espaço, pois os concursos são a via de acesso para que, a partir de uma suspensão do tempo cotidiano do trabalho e dos estudos, esses sujeitos da "periferia" possam estabelecer, no espaço da "quadra", as disputas que são encenadas nos concursos. Para além de quadra junina, essas festividades são genericamente denominadas como São João, visando destacar um período específico do ano, o mês de junho, em que um santo católico (São João) é, de algum modo, "despersonificado" - ganhando, até certo ponto, um caráter laico - e transformado em um conjunto de acontecimentos: o ciclo festivo junino muito marcado por certames ritualizados. ${ }^{8}$

As análises aqui compartilhadas referem-se às observações que realizei (nos ensaios e concursos juninos) acerca das práticas coreográficas empreendidas por quadrilhas que se reconhecem como coletivos produtores de cultura popular na cidade de Belém. Isto é, são grupos que se autodenominam como quadrilhas juninas possuidoras de um caráter profissional em suas práticas com vistas a disputar os certames oficiais promovidos pela FUMBEL e FCP, compondo uma agenda de apresentações culturais no calendário festivo de Belém e do Estado do Pará. Essas quadrilhas possuem uma diretoria e uma equipe de produção que coloca em andamento os seus projetos coreográficos, trabalhando com cronogramas específicos de ensaios. Mais do que isso, as quadrilhas (por meio de seus representantes) discutem com o Estado tanto as políticas voltadas para os grupos de cultura popular quanto as regulações que o próprio Estado tenta propor (ou impor?) à quadra junina de Belém através dos editais que regulamentam os certames disputados pelos quadrilheiros. ${ }^{9}$

\footnotetext{
8 Luciana Chianca (2007a:54-55) registra certo processo de laicização das festas juninas e sua crescente perda de vínculos com a Igreja Católica.

9 Devido ao escopo deste artigo, não abordarei essa discussão em torno das regulações sobre o São João de Belém.
} 
Por outro lado, não se pode resumir esse contexto de atuação profissional quadrilheira ao âmbito dos concursos promovidos pela Prefeitura Municipal de Belém ou pelo Governo do Estado do Pará. Destaco que nas "periferias" de Belém há inúmeros concursos juninos que são resultantes de inciativas de produtores culturais diversos e de lideranças comunitárias que visam dinamizar a vida cultural de certos bairros da cidade. Tais certames possuem editais de regulação e exigem dos quadrilheiros a mesma conduta e qualidade profissional dedicada aos concursos promovidos pelos poderes públicos locais. Em outras palavras, meu interesse de análise está centrado nesses grupos coreográficos profissionais, o que exclui da apreciação crítica outras possíveis manifestações quadrilheiras tais como as quadrilhas juninas em contextos escolares (que se constituem como uma atividade didática de um calendário letivo em escolas de ensino fundamental e médio) ou mesmo quadrilhas formadas por grupos de pessoas que realizam festejos em igrejas, praças, associações de bairro ou em quaisquer outros espaços e contextos nos quais o caráter profissional, sistemático e de extrema regulação não seja verificado nem reconhecido como condizente aos padróes de dinâmicas de produção estabelecidos, pelos próprios quadrilheiros, como elementos que evidenciam o alto grau de profissionalização de certos grupos de cultura popular. Ressalto ainda que as considerações presentes neste artigo são advindas de muitos meses dedicados ao trabalho de campo - nos ensaios de quadrilha, nos ateliês de produção de trajes juninos, nos certames oficiais ou nos concursos juninos das "periferias" - com o intuito de acompanhar todo o processo de preparação $e$ realização do São João de Belém. ${ }^{10}$

\footnotetext{
${ }^{10}$ Em 2012, realizei trabalho de campo nos certames oficiais durante todo o mês de junho. Em 2013, pesquisei durante os meses de janeiro e fevereiro. Em 2014, o trabalho de campo estendeu-se de janeiro a agosto. Em 2015, fui a campo durante o mês de maio. Em 2016, fechei o campo realizando imersões etnográficas nos concursos das "periferias" e nos concursos oficiais durante o mês de junho e julho. Vale ressaltar que em agosto de 2016, realizei trabalho de campo nos concursos nacionais de Quadrilhas e Rainhas Juninas que, pela
} 
Para empreender as análises dispostas adiante, parto do princípio de que as quadrilhas juninas, consideradas como danças que integram um conjunto de manifestações da cultura popular, são igualmente elaboradas como narrativas ancoradas em personagens. Indo mais além, sugiro que as quadrilhas se configuram como danças que colocam em cena certos dramas. Expressariam dramas sociais a partir do modelo proposto por Victor Turner (2008)? Estariam conectados, como propõe Schechner (1988; 2012), os dramas sociais e os dramas estéticos? E como todas essas coisas podem estar interligadas às discussões sobre gênero e sexualidade?

De início, sugiro apenas que, para além de jogo, os concursos juninos são rituais que, coreograficamente, podem expressar dramas sociais. Particularmente, interessa-me analisar possíveis dramas sociais e estéticos conectados a problemáticas de gênero e de sexualidade inseridos no contexto quadrilheiro. Assim, compartilho da ideia de que

\begin{abstract}
muitos dramas sociais contêm, mesmo que apenas implicitamente, meios de reflexividade pública em seus processos reparadores. Ao ativá-los, os grupos avaliam a sua situação atual: a natureza e a força de seus laços sociais, o poder de seus símbolos, a eficácia de seus controles morais e legais, a sacralidade de suas tradições religiosas, e assim por diante (Turner, 2005b:182-183).
\end{abstract}

Se é possível considerar que dançar quadrilha é uma performance que integra um contexto ritual (os concursos juninos), pergunto: em que medida essas danças expressariam, a partir de uma dinâmica ritualizada, dramas sociais? Se esses dramas sociais estão realmente codificados em movimentos corporais, é necessário tentar apreendê-los a partir dos significados que as coreografias juninas nos comunicam. Como ponto de partida, é preciso identificar que as quadrilhas são códigos

primeira vez na história do movimento junino nacional, ocorreram em Belém. No total, foram 15 meses de pesquisa em campo. 
coreográficos que expressam um enredo dramatizado por personagens que compóem a cena. De acordo com Chianca (2006; 2013a), no formato em que são apresentadas na região nordeste do Brasil (e eu acrescentaria em muitas outras regiões), as quadrilhas encenam uma celebração em torno de um possível casamento entre uma moça desvirginada (e muitas vezes grávida) e um rapaz que não quer ser responsabilizado pela iniciação sexual dessa jovem. Embora essa narrativa nem sempre seja encenada dessa maneira, admitindo muitos tipos de variações e adaptações, grande parte dos grupos juninos do Brasil encena temáticas nas quais o casamento é o elemento central. Tomarei essa ideia de casamento e o enredo descrito por Chianca (2006; 2013a) como ponto de referência para tratar das questões aqui abordadas.

Em Belém, as quadrilhas não apresentam, compulsoriamente, uma narrativa pautada na celebração de um casamento. ${ }^{11}$ O casamento é subentendido, omitido, "ignorado" ou, em algumas raras coreografias, celebrado. Antes que tais enredos sejam devidamente analisados com mais profundidade, sugiro que, em primeiro lugar, sejam expostos aqui os principais personagens que integram as quadrilhas e suas respectivas funções coreográficas. Deve-se considerar que a dança popular ou erudita, em suas mais variadas acepções culturais e práticas performáticas, é, em grande parte, pautada em divisões binárias de gênero. $\mathrm{Ou}$ seja, a dança é um código performático generificado.

Baseado nessa concepção, apresentarei os personagens quadrilheiros como elementos estruturais que compõem $e$ dinamizam a estrutura dramática das narrativas juninas, tal qual pude depreendê-los durante o trabalho de campo. Configuram-se como personagens estruturantes dessas narrativas juninas os marcadores, os cavalheiros, as misses e as damas, apresentados

\footnotetext{
${ }^{11}$ Nos concursos de Belém, o casamento não é obrigatório e os noivos não são personagens que necessariamente devem integrar a quadrilha. Entretanto, quando os grupos de Belém vão disputar concursos de abrangência nacional, o par de noivos e uma cena de casamento são inseridos na narrativa.
} 
individualmente nos tópicos a seguir. Após esta primeira apresentação dos personagens estruturais das narrativas juninas, destaco, do ponto de vista do gênero e da sexualidade, alguns elementos estruturalmente arredios (Turner, 1987), isto é, personagens que, na estrutura narrativa junina, borram concepções estanques de gênero $e$ sexualidade $e$, por consequência, complexificam o drama encenado, tanto em seu plano estético quanto social. Assim, apresentarei nos tópicos seguintes outros marcadores, cavalheiros, misses e damas que compõem e desestabilizam o caráter binário dos personagens juninos em termos de categorias generificadas e sexualizadas. Por fim, proponho uma análise dos significados subjacentes à possibilidade de realização ou não de uma performance de casamento no interior das composições coreográficas juninas de Belém. A seguir, a apresentação dos personagens.

\section{Marcadores}

O marcador ${ }^{12}$ de quadrilha é uma espécie de mestre de cerimônia que apresenta a quadrilha ao público e ao corpo de jurados, anuncia os passos de dança que a quadrilha deve executar e, por fim, constitui-se como um sujeito que estabelece canais de intermediação, interação e diálogo entre a quadrilha, o júri e o público, dando inteligibilidade ao enredo coreográfico narrado pelos passos de dança. Mais do que isso, o marcador é um sujeito cênico situado, concomitantemente, dentro e fora da quadrilha, sendo brincante e, ao mesmo tempo, uma representação performática de todos os integrantes da diretoria da quadrilha, pois uma de suas atribuições mais relevantes é a organização cênica e espacial do grupo para que seja bem avaliado pelo corpo de jurados. O marcador ocupa uma zona de liminaridade, pois, de forma ambivalente, pertence ao coletivo de

\footnotetext{
${ }^{12}$ Ressalto que utilizo a nomenclatura corrente no contexto quadrilheiro de Belém. Em outros estados brasileiros, esse personagem pode ser denominado como animador, gritador etc.
} 
dançarinos e constitui-se como membro que personifica a diretoria e a equipe de produção da quadrilha. Como um personagem da quadrilha, o marcador sempre vem caracterizado com trajes que comunicam algo sobre seu lugar performático liminar no contexto da coreografia que será apresentada. Nesse caso, o marcador integra a narrativa a partir de uma posição de autoridade coreográfica e alteridade cênica, que o coloca na condição de condutor da narrativa e, por isso, exige que seus personagens sejam, dentre as opções possíveis, ambíguos, autoritários, loucos, engraçados ou memoráveis. Além de sua condição liminar, há outro fato relevante que me despertou a atenção em campo: as marcas do gênero e da sexualidade associadas à figura do marcador tanto em sua atuação cênica quanto em sua vida pessoal. De maneira quase invariável, o marcador é sempre um homem cisgênero cuja sexualidade é presumida ou, muitas vezes, indubitavelmente atribuída como heterossexual.

\section{Cavalheiros}

Os cavalheiros são o conjunto de integrantes "masculinos" de uma quadrilha, representam todos os atributos de "masculinidade" que são encenados coreograficamente. Se é possível convencer-se de que as festas juninas, como momentos rituais, expressam, reforçam e exageram certos ideais de ruralidade e conjugalidade, é também possível notar que, dentro dessa configuração, os cavalheiros performatizam a força de trabalho do homem do campo, o desejo sexual "masculino" implícito no cortejo às damas e os elementos distintivos de uma masculinidade adequada para produzir a oposição binária estrutural, cavalheiros/damas, na qual se baseia todo o enredo coreográfico das quadrilhas.

No que se refere aos trajes dos cavalheiros, há uma evidência importante, perceptível a qualquer observador leigo: suas roupas devem seguir os mesmos padrões de cores, tecidos, acessórios e materiais utilizados para fazer o traje das damas. Em outras palavras, cavalheiros e damas devem demonstrar um 
vínculo ou intenção de vínculo conjugal que é notado pela combinação estrita de suas roupas. Mais do que isso, os trajes significam também a existência de um vínculo comunitário entre todos os sujeitos "masculinos" $e$ "femininos" que integram a quadrilha, tendo em vista que suas roupas, repartidas por uma oposição binária de gênero, são iguais, uniformizando "homens" e "mulheres" que denotam "masculinidades" e "feminilidades" coreográficas. ${ }^{13}$ Vestidos como cavalheiros e damas, tais sujeitos ostentam uma identidade comunitária evidenciada pelos trajes. as roupas parecem indicar um pertencimento social.

\section{Misses}

As misses são as brincantes mais importantes de toda $e$ qualquer quadrilha. Disputam títulos de reconhecimento que estão diretamente relacionados à avaliação de sua beleza, seu traje e suas habilidades em dança. Antes de cada quadrilha se apresentar para um júri especializado, as misses que a representam dançam e investem na conquista de um título correspondente à sua categoria. Essas dançarinas possuem um concurso à parte, que ocorre em paralelo aos certames de quadrilha. Estão subdivididas nas categorias Miss Caipira, Miss Mulata (ou Miss Morena

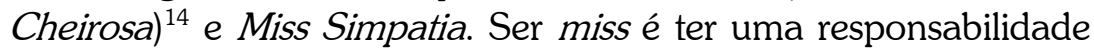
imensa para com a quadrilha, pois, como sugiro, o trabalho de campo me fez perceber que há uma relação metonímica entre a miss e a sua quadrilha, de modo que, reciprocamente, uma se torna significante da outra.

Embora sejam damas, as misses operam no registro coreográfico do extraordinário. Suas roupas não combinam com os trajes de nenhum outro brincante, seja ele cavalheiro, dama ou marcador. Seu traje é desconexo do grupo em termos de estampa

\footnotetext{
${ }^{13}$ Entendo que os conceitos de "masculino" e "feminino" e seus correlatos são construções culturais, sociais, políticas e históricas. Portanto, para desnaturalizálos, utilizarei aspas quando me referir a eles.

${ }^{14}$ Por questões de escopo do trabalho, não abordarei aqui as implicações raciais dessas categorias.
} 
de tecido, padrões de cores, arranjo de cabeça, maquiagem, acessórios (pulseiras, colares), objetos cênicos e todo e qualquer material utilizado na confecção de sua roupa. Em outras palavras, as misses possuem a liberdade de construir um traje específico, que traduza em roupa, o tema da performance que apresentará ao público e aos jurados. Não são obrigadas a vestirem roupas que estejam em acordo com o padrão de cores e a estamparia dos tecidos escolhidos pela quadrilha. Não pretendo afirmar que as misses têm amplo poder de escolha quanto ao traje. Sua roupa é desenhada e confeccionada por estilistas cujo trabalho visa acompanhar proposta coreográfica pensada pelos coreógrafos da miss. Assim, seu traje segue um padrão estético reconhecido, pelos quadrilheiros, como tipicamente junino. No entanto, de acordo com os critérios de avaliação estabelecidos em editais específicos e adotados pelo corpo de jurados que as analisam, as misses utilizam trajes que estão desobrigados da ideia de combinação com outros brincantes de sua quadrilha. Junto com sua equipe de estilistas e coreógrafos, as misses possuem relativa liberdade para escolherem seus temas performáticos. Com exceção da Miss Caipira, a mais proeminente entre as misses, cuja obrigação é dançar um tema que esteja minimamente vinculado à temática central abordada por sua quadrilha.

As misses possuem uma afinidade específica com os marcadores. compartilham uma mesma condição de liminaridade. Essas personagens "femininas" são também sujeitos liminares por estarem, ao mesmo tempo, dentro e fora da estrutura narrativa das quadrilhas juninas. Se os trajes de damas e cavalheiros (e sua combinação em termos de estampas e materiais) podem ser interpretados como símbolos rituais que denotam vínculos ou intenção de vínculos conjugais e sexuais entre os polos "feminino" e "masculino" das quadrilhas, é possível sugerir que, apesar de integrarem o grupo de damas, as misses estão aquém e além dele, demonstrando, em seus trajes diferenciados, sua condição de damas que não possuem ligações concretas com nenhum outro cavalheiro da quadrilha. Em outras palavras, se as quadrilhas empreendem uma performance na qual está em jogo o 
estabelecimento de laços de parentesco entre damas e cavalheiros, as misses constituem-se como personagens "femininas" que borram as convenções tradicionais de parentesco, pois aparentam não estar disponíveis nesse sistema de trocas matrimoniais. Divididas entre três categorias, essas misses são referidas pelos quadrilheiros como Misses Mulheres, numa nomenclatura que as diferenciará das Misses Gays ou Mix abordadas adiante.

\section{Damas}

As damas são o conjunto de brincantes "femininas" que compõem uma quadrilha. Embora haja uma presença "masculina" importante, materializada pelos marcadores $e$ cavalheiros, grande parte do público externo e dos próprios sujeitos que produzem as festas juninas reconhece que a porção "feminina" das quadrilhas é a que mais se destaca nesse contexto. É como se todo o discurso coreográfico fosse elaborado em função das damas, feito para exibi-las em termos de qualificadores que os quadrilheiros avaliam como "graciosidade", "beleza", "delicadeza" ou algum outro atributo que esteja incrustrado em concepções de "feminilidade" veiculadas no senso comum. Tal qual os cavalheiros, as damas precisam estar com trajes que denotem um vínculo ou intenção de vínculo conjugal com a parte masculina do grupo. Suas roupas, portanto, devem ser confeccionadas com os mesmos tecidos, cores e materiais utilizados nos trajes dos cavalheiros. Desse ponto de vista, as roupas dos brincantes fazem referência a uma suposta $e$ idealizada harmonia grupal, ou seja, um senso de comunidade pautado na perpetuação de laços afetivos e sexuais responsáveis pela continuidade de redes de parentesco que estão baseadas em uma heterossexualidade presumível e desejável.

\section{Outros marcadores}

Durante trabalho de campo, conheci Danna Moraes, uma travesti que, tendo uma longa trajetória quadrilheira como 
cavalheiro, dama e miss gay, agora investia no desempenho de funções como marcadora de quadrilha. Diante de um cargo estritamente vinculado à ideia de "masculinidade" ou, pelo menos, de fixidez do gênero, seja ele "masculino" ou "feminino", a emergência de uma travesti para desempenhar a função de marcadora surge como um ato subversivo das lógicas quadrilheiras, pois inscreve uma "feminilidade" ambivalente e uma sexualidade não heterossexual no centro propulsor da quadrilha, ou seja, no cargo projetado para o exercício do poder de comando sobre o grupo durante todo o processo de ensaios $e$ apresentações de suas performances nos concursos juninos. Ao desestabilizar a "masculinidade" vigente e hegemônica no cargo de marcador, a categoria travesti configura-se como uma presença perturbadora de um ordenamento de gênero e sexualidade já bem estabelecidos nos concursos juninos. A emergência desses sujeitos desafia as lógicas quadrilheiras e parece anunciar mudanças.

\section{Outros cavalheiros}

$\mathrm{Na}$ quadra junina de Belém, são inúmeros os casos de cavalheiros que não correspondem aos padrões hegemônicos de "masculinidade" e heterossexualidade. Trago aqui apenas dois exemplos de cavalheiros, ilustrados por Camila Marquezyne (travesti que dança na Sedução Ranchista, bairro do Jurunas) e Fantiny Dourado (garoto transgênero da Tradição Junina, bairro do Benguí). Ambos não ocupam o cargo de damas em suas respectivas quadrilhas por impedimentos internos que foram impostos pela diretoria desses grupos, embora os regulamentos dos certames juninos financiados pelos poderes públicos locais (Prefeitura de Belém e Governo do Pará) não os impeça de dançar em posições coreográficas "femininas".

Mas quero trazer ainda um caso paradigmático envolvendo dois cavalheiros que também são da Tradição Junina do Benguí. Em 2014, a quadrilha resolveu colocar em cena um beijo gay, inserindo-o numa brincadeira tradicional das festas juninas: a barraca do beijo. A cena foi construída da seguinte forma: nos 
minutos finais da coreografia, quatro cavalheiros trazem para o centro do espaço cênico uma barraca do beijo. As três misses da quadrilha (Miss Caipira, Miss Mulata e Miss Simpatia) adentram a barraca para aguardar o beijo de algum cavalheiro do grupo. Três cavalheiros beijam cada uma das misses. Porém, quando um quarto cavalheiro distraído se dirige à barraca com o intuito procurar uma dama para beijá-la, eis que surge de dentro da barraca outro cavalheiro. Diante do inusitado, o cavalheiro surpreendido demonstra espanto e dúvida ao olhar para o conjunto de brincantes. Por sua vez, os brincantes, acompanhados também pelas vozes da torcida, gritam: "Bei-ja! Bei-ja! Bei-ja!". Ao ouvir o estímulo de seus companheiros e do público, os dois cavalheiros se beijam. O beijo foi protagonizado pelo casal de cavalheiros Mayk e Dênis. Os dois se conheceram no período de ensaios da Tradição Junina do Benguí, mais precisamente no mês de março, quando Dênis ingressou no grupo do qual Mayk já fazia parte. Embora fossem, de fato, um casal de namorados, Mayk $e$ Dênis não configuravam um par em sua quadrilha, pois pares compostos por pessoas do mesmo gênero são terminantemente inadmissíveis. Durante todo o desenvolvimento da coreografia, ambos só poderiam formar pares com as damas disponíveis na quadrilha. Contudo, no fortuito momento da barraca do beijo, a hegemonia heterossexual da coreografia foi temporariamente quebrada e desafiada.

Apesar de ter havido esse momento cênico de caráter homossexual, a performance de Mayk e Dênis, durante todo o restante do desenvolvimento da coreografia, reforçava a "masculinidade" do grupo de cavalheiros, enfatizando a encenação de relações heterossexuais com as damas e evitando, do ponto de vista do gênero, elementos gestuais que pudessem provocar efeitos de "feminilidade" considerados como contaminadores à performance do "masculino". Contudo, no que diz respeito à sexualidade, o beijo gay representou um desafio à "masculinidade" hegemônica como norma, pois, de algum modo, tal performance estimula a suposição de que, entre aquele casal homossexual, haverá pelo menos um dos sujeitos que 
desempenhará o papel sexual rotulado, pejorativamente, como "passivo". Esse fator é, em geral, percebido socialmente como um elemento que feminiliza a figura "masculina", atrelando à sua sexualidade certa aproximação com campo de expressão dos desejos sexuais "femininos". ${ }^{15}$

\section{Outras misses}

Há uma quarta categoria de miss que, nessa interpretação que estou tentando construir à luz das teorias de ritual $e$ performance, configura-se como um elemento estruturalmente arredio no plano performático das quadrilhas juninas. Essa quarta categoria é denominada pelos quadrilheiros, em seus próprios termos êmicos, como Miss Gay ou Miss Mix. Trata-se de uma categoria englobante, representada pelos termos "gay" ou "mix", que abrange homens gays, travestis, mulheres transexuais $e$ pessoas transgênero. Em outras palavras, a categoria gay/mix refere-se a todos aqueles sujeitos que, na lógica quadrilheira, não são reconhecidos como mulheres.

Em termos comparativos, a Miss Mix é idêntica à Miss Mulher em alguns aspectos: dança uma coreografia com duração de dois minutos e interpreta personagens que fogem a certas classificações estruturais. Ao acompanhar os certames com frequência, é perceptível que essas personagens são quase sempre bruxas, fadas, ciganas, escravas, seres mitológicos da Amazônia, indígenas, orixás, caboclos, encantados, prostitutas, mágicas, animais e uma infinidade de outros seres e sujeitos que habitam o universo mágico, religioso, sexual, não ocidental $e$, em alguns casos, fantasioso. ${ }^{16}$ De todo modo, essas personagens

\footnotetext{
${ }^{15}$ Essa explicação será útil para que se entenda, mais adiante, a noção de sujeitos da feminilidade. Embora não estejam performatizando o "feminino", Mayk e Dênis encenam uma interação homossexual que dá margem à suposição de possíveis papéis sexuais "ativos" e "passivos" entre o casal, fator que pode ser percebido como elemento que feminiliza um ou ambos os integrantes do casal.

${ }^{16}$ Para uma problematização mais extensa e detalhada sobre os concursos de Miss Caipira Gay e Miss Caipira Mix, ver Noleto (2014).
} 
demonstram escapar aos sistemas classificatórios formalmente admitidos na estrutura social e política por nós compartilhada. Isto é, as personagens interpretadas coreograficamente pelas Misses Gays, tal qual como ocorre com as Misses Mulheres, são caracterizadas por uma condição de liminaridade, que as coloca betwixt and between (Turner, 2005) em relação a uma estrutura social que nos é familiar.

\section{Outras damas}

Em um primeiro momento, quando apresentei os personagens que estruturam o drama junino, mostrei as damas do modo como elas são idealizadas pela lógica quadrilheira: um grupo composto por jovens mulheres cisgênero heterossexuais. No entanto, há fatores que embaraçam essa compreensão simplificada e idealizada acerca do grupo de damas. Estou me referindo aos homens homossexuais, às travestis, às mulheres transexuais e às pessoas transgênero que ocupam cargos de damas em suas respectivas quadrilhas. Misturadas às mulheres cisgênero heterossexuais, essas pessoas "trans" complexificam o entendimento binário dos gêneros nesse contexto coreográfico marcadamente dividido entre damas e cavalheiros. Ainda que haja uma pluralidade identitária no contexto das damas, é a transexualidade que se mantém como identidade predominante. Experiências como as das damas Evelyn Lobo (quadrilha Renovação de São João, bairro da Condor), Letícia Alcolumbre e Sammy Soares (quadrilha Encanto Tropical, bairro do Tapanã), mulheres transexuais que ocupam o cargo de damas, falam acerca da vivência de uma identidade transexual no contexto junino. $\mathrm{O}$ ponto de encontro entre os discursos dessas três mulheres transexuais reside exatamente na valorização dada aos concursos juninos como acontecimentos relevantes para o processo de reconhecimento de suas identidades de gênero "femininas" no âmbito social. Suas falas abordam - em termos êmicos como "cirurgia", "normalidade" e "respeito" - temas como transgenitalização e despatologização da transexualidade, 
reivindicando uma cidadania trans que é, em parte, legitimada por suas posições coreográficas no São João, mas que seria melhor ratificada pela realização do sonho cultivado de efetivar um processo de redesignação sexual, conforme relataram, de modo emocionado, Evelyn e Letícia. ${ }^{17}$

Embora a transexualidade seja a identidade sexual e de gênero mais evidente nesse conjunto de damas, configurando-se como o elemento estruturalmente arredio que melhor redesenha os contornos do "feminino" nesse âmbito coreográfico, é impossível não perceber que também existem (embora em menor número) outras identidades sexuais e de gênero que integram o grupo de damas tais como as travestis e os homens transgênero, isto é, sujeitos que são reconhecidos por adotarem identidades "femininas", mesmo que de modo transitório. Ainda que com identidades diferentes entre si, mas que se aproximam devido ao trânsito pela "feminilidade", esses sujeitos estão aglutinados sob uma mesma categoria, as damas. Contudo, não são experiências identitárias idênticas. Se há essa diferenciação apresentada pelo contexto etnográfico, a categoria dama precisa ser pensada nesses termos. Isto é, o campo mostrou-me a necessidade de forjar uma categoria que pudesse definir a especificidade daquilo que os quadrilheiros consideram como "feminino" e, simultaneamente, marcar certa dissidência de um gênero "feminino" considerado em termos hegemônicos e biológicos. Sugiro, portanto, que a categoria dama mix é ideal para designar a pluralidade de sujeitos que não são reconhecidos plenamente como mulheres. $\mathrm{O}$ adjetivo mix advém do próprio contexto junino, no qual os concursos de Miss Gay, destinados a todas aquelas pessoas que não são consideradas como mulheres pelos quadrilheiros (gays, travestis, transexuais e transgênero), são também denominados como concursos de Miss Mix. Isso implica dizer que o significado da expressão mix está pautado na ideia de mistura, traduzida pela aglutinação de diferentes identidades sexuais e de gênero sob uma

${ }^{17}$ Sobre a controvérsia em torno da despatologização da transexualidade, ver Butler (2009) e Bento e Pelúcio (2012). 
mesma categoria. Diante disso, acredito que o empréstimo do adjetivo mix, recolhido dos concursos juninos de Miss Gay, é válido para também designar a complexidade de identidades sexuais e de gênero que perfaz o conjunto de damas.

\section{Sujeitos da feminilidade}

Mas como pensar nesses personagens juninos que desestabilizam a inteligibilidade binária do gênero $e$ da sexualidade? De algum modo, o fator perturbador que reconfigura a divisão generificada $e$ a pressuposição da heterossexualidade nas narrativas juninas está ligado à presença de "feminilidades" indesejáveis no contexto performático. Essas "feminilidades" indesejáveis se materializam no fato de que as quadrilhas juninas de Belém abriram-se à possibilidade de operar, atualmente, com marcadoras transexuais, com misses e damas mix e com cavalheiros interpretados por travestis ou pessoas transgêneros; ou ainda cavalheiros que afirmam sua homossexualidade, não escondendo aspectos "femininos" que integram a sua sexualidade como, por exemplo, a suposição de "passividade" sexual entre cavalheiros reconhecidamente gays.

O trabalho de campo me fez perceber que todos esses sujeitos, marcados por "feminilidades" indiscretas, são alocados no mesmo patamar, pois meus interlocutores em campo os consideram como categoria unívoca, embora suas diferenças idiossincráticas sejam plenamente conhecidas no convívio quadrilheiro. Isso significa dizer que, no vocabulário cotidiano dos quadrilheiros, todos aqueles sujeitos que, de algum modo, inscrevem em seus corpos uma "feminilidade" proeminente, conjugada a um comportamento sexual mais próximo à homossexualidade, são definidos como "as gays". Esse termo, comumente usado para designar homens homossexuais, é então alargado para abarcar outras categorias de gênero e sexualidade. Assim, "as gays", expressão sempre referida no "feminino", é usada de modo englobante para denominar homens gays, travestis, mulheres transexuais e pessoas transgênero. 
Mais do que isso, percebi que muitos quadrilheiros usam, esporadicamente, essa categoria (as gays) também para referir-se a mulheres que ostentam uma "feminilidade" exacerbada para fora dos padrões do recato ou de uma sensualidade discreta. Essas mulheres, "frescam muito, parecem viados", como me disse certa vez Sharize Ariell, um homem transgênero que disputa concursos de Miss Mix e coreografa Misses Mulheres. Em sua opinião, tais mulheres, para serem boas misses, tem que "frescar que nem as gays". Nesse sentido, o verbo frescar refere-se ao investimento em passos de dança e numa gestualidade exageradamente "femininos", indo em direção a uma "feminilidade" discordante do padrão hegemônico percebido entre as demais damas das quadrilhas. Em geral, essa "feminilidade" exacerbada é empreendida pelas misses e quase nunca pelas damas. $\mathrm{O}$ que importa reter aqui é o fato de que, em muitas situações reais, os quadrilheiros referem-se a diversas identidades sexuais e de gênero como categorias sinônimas no intuito de favorecer um uso mais ágil da linguagem em suas interações cotidianas, reforçando a compreensão êmica de que os termos "gay" ou "viado" são mobilizados como categorias guarda-chuva para designar uma multiplicidade de sujeitos. Dessa maneira, agrupam homens gays (que podem ser cavalheiros, misses ou damas mix), travestis (que dançam como misses ou damas mix, mas também podem ser cavalheiros), mulheres transexuais (predominantes no campo das damas mix), homens transgêneros (que podem dançar como cavalheiros, misses ou damas mix) e até mulheres cisgênero (que ocupam os cargos de misses e damas).

A lógica que agrupa diferentes categorias políticas de sujeitos sexuais está baseada no fato de que são sujeitos da feminilidade, isto é, brincantes que imprimem a marca do "feminino" nas quadrilhas juninas. Forjei essa categoria englobante por entender que, em termos analíticos, causaria menos confusão do que o uso do termo "gay" como categoria universalizante para todas essas identidades. Ao meu ver, essa categoria, sujeitos da feminilidade, não inclui apenas os homossexuais e pessoas trans, mas as próprias mulheres cisgênero 
que, no conjunto de brincantes, produzem o "feminino" não hegemônico em cena. Em outras palavras, os sujeitos da feminilidade - categoria analítica que abrange mulheres cisgênero, mulheres transexuais, travestis, pessoas transgênero e homens homossexuais - representam identidades coreográficas, marcadas pela dança, que produzem efeitos de feminilidade no contexto dos concursos juninos de quadrilhas e de misses em Belém. A compreensão dessas categorias do "feminino" será importante para a problematização de como essas personagens reconfiguram no plano estético toda uma discussão sobre casamento $e$ parentesco no plano social.

\section{Casamento em performance}

Conhecidos os personagens, passemos ao possível drama. Para falar acerca do casamento no âmbito junino, recorro aos trabalhos publicados por Luciana Chianca (2006; 2007a; 2007b; 2013a; 2013b) nos quais o casamento é colocado como elemento central das narrativas juninas. De acordo com a autora,

trata-se de um cenário que se constrói através do seguinte roteiro: um jovem rapaz engravida sua namorada $e$ se recusa a casar diante dos seus pais e dos da noiva geralmente compadres pertencendo a níveis sociais hierárquicos diferentes. Como geralmente um dos pais é "coronel", "prefeito", "fazendeiro", a atitude dos noivos contrasta muito: o noivo quer fugir e a noiva espera ansiosa pela união. A presença do conjunto da comunidade (os convidados) e suas principais autoridades civis e religiosas (policiais, juiz de direito e padre), além dos pais de ambos os nubentes não são suficientes para coagir o noivo que tenta inúmeras vezes fugir do enlace. A presença - prudente - de autoridades policiais é ineficaz até que, sob ameaça de facas, revólveres e até canhões (!) ele desiste de escapar e aceita seu destino de homem casado e futuro pai de família. A "honra" da noiva e de sua família estão salvas (Chianca, 2013a:41). 
Apesar de reconhecer o casamento como elemento central das narrativas juninas, Chianca não o problematiza à luz do arcabouço teórico antropológico construído em torno dos rituais. Suas análises possuem um acento mais histórico, descritivo e de constatação, que denota um intento de reconstruir continuidades $e$ rupturas na forma de realização dos festejos juninos na cidade de Natal (Chianca, 2006), demonstrando especial atenção a temáticas relacionadas à migração de sujeitos do interior para transformarem-se em brincantes na capital (Chianca, 2006; 2007b). Tal tipo de análise possibilita que Chianca elabore algumas reflexões acerca da emergência da figura do "matuto" como personagem protagonista das festividades de junho (Chianca, 2007b). Ou seja, a autora não aborda o ciclo junino de um ponto de vista no qual o ritual é analisado de modo exegético. Sua opção por não dialogar mais detidamente com o legado teórico de Turner (2013) e Van Gennep (2011), dois dos tantos autores centrais para o debate antropológico sobre rituais, evidencia que o caráter ritual das festas juninas é reconhecido, mas não demonstrado $e$ problematizado em suas instâncias mais profundas. Assim, abordo a temática das festas juninas a partir de outra perspectiva: procuro compreender os rendimentos simbólicos do casamento como centro dramático da narrativa junina, interrogando-o em seu conteúdo semântico e buscando realizar uma exegese que o articula às dimensões de produção do gênero, da sexualidade e das configurações dos sistemas de parentesco. É nesse sentido que pretendo contribuir: atentando para a face simbólica dos rituais e tentando empreender uma análise que privilegie de modo mais estrito um diálogo com as teorias de ritual e de performance.

Sabe-se que a narrativa em torno do casamento é parte constitutiva de grande parcela das performances quadrilheiras em diversas regiões do país, inclusive em Belém. No entanto, as quadrilhas de Belém não tem no casamento um centro propulsor da narrativa, isto é, a celebração do casamento não se constitui como uma obrigatoriedade, podendo ser realizada, subentendida ou ignorada. Embora não se possa afirmar que o casamento é por 
completo inexistente nas quadrilhas de Belém, pode-se dizer que sua ausência obstinada e muito perceptível em inúmeros grupos juninos tem implicações de grande valia para o debate sobre gênero, sexualidade e parentesco.

Contudo, no que tange o matrimônio, pretendo iniciar a discussão pressupondo a existência e a exigência da celebração do casamento nas performances quadrilheiras do Pará e de muitos outros estados brasileiros. Não é difícil supor que a narrativa junina, considerada em sua totalidade sequencial, configura um enredo linear que parte de um conflito instaurado e finda em sua possível resolução. Eis aí a estrutura processual do drama social delineada por Victor Turner. Para o autor, os dramas sociais são "episódios de irrupção pública de tensão" evidenciados "quando os interesses e atitudes de grupos e indivíduos encontravam-se em óbvia oposição", constituindo-se como "unidades do processo social isoláveis e passíveis de uma descrição pormenorizada" (Turner, 2008:28). Dramas sociais possuem a seguinte estrutura processual: ruptura, crise, ação corretiva $e$, finalmente, a reintegração ou cisão. ${ }^{18}$ Vistos dessa maneira processual, os dramas sociais guardam em si um caráter ficcional e poético (Cavalcanti, 2007:130).

No caso de minha pesquisa, as festas juninas não podem ser propriamente consideradas como dramas sociais em curso, mas como dramas estéticos (Schechner, 2012) que podem ser compreendidos a partir da estrutura do drama social. A partir da conexão entre dramas sociais e estéticos, como pensar no drama estético junino do casamento com base nessa estrutura processual do drama social? ${ }^{19}$ Sugiro que o enredo tecido em torno do matrimônio é iniciado com uma ruptura significativa: um rapaz desvirgina e engravida uma moça, recusando-se a casar-se com

\footnotetext{
${ }^{18}$ Para problematizações mais detalhadas sobre o conceito de drama social e sua estrutura processual, ver Turner (2005a; 2008) e Cavalcanti (2007; 2012).

${ }^{19}$ Para outras reflexões sobre os vínculos entre dramas sociais e estéticos sugeridos pelo infinity-loop model desenhado por Schechner (1988; 2012), ver Silva (2005), Dawsey (2011) e Dawsey, Müller, Hikiji e Monteiro (2013).
} 
ela e violando a norma social da moralidade pautada na virgindade feminina como um valor. Como crise, pode-se considerar o alargamento do conflito a partir das estratégias de perseguição que o pai da noiva e outras autoridades jurídicas, civis, militares e/ou religiosas empreendem para obrigar o deflorador a casar-se com a moça desvirginada. Caso haja insistência na recusa ao casamento, a outra possibilidade de resolução do conflito é o assassinato do jovem rapaz a mando do chefe da família que fora desonrada. No que tange a ação corretiva ou reparadora, a celebração do casamento é finalmente acordada entre as partes e emerge como possível mecanismo de suspensão do conflito, capaz de restaurar a honra de todos os sujeitos envolvidos no enredo. Assim, como última fase processual, tem-se a reintegração entre grupos, materializada pelo estabelecimento de relações mais cordiais entre duas famílias que possuem agora um vínculo de parentesco. ${ }^{20}$

Se é possível convencer-se de que o drama estético junino segue a estrutura processual descrita, pergunto: a que dramas sociais ele faz referência? Sugiro que as quadrilhas juninas referem-se, como drama social, ao dilema da atribuição da paternidade e à possível ameaça de suspensão de um sistema de relações de parentesco baseado em casamentos moralmente legitimados pelos preceitos cristãos da virgindade feminina e da sexualidade reprodutiva como valores estruturantes. ${ }^{21}$ Trata-se de

${ }^{20}$ É válido lembrar que as narrativas juninas, atualmente, possuem muitas variações. Os enredos são modificados e sofisticados anualmente, ratificando a dinâmica desse campo de produção simbólica. Entretanto, se analisados detalhadamente, é possível perceber que os projetos coreográficos juninos mobilizam, com grande frequência, narrativas que recorrem à estrutura processual do drama social (ruptura, crise, ação corretiva e reintegração ou cisão) e estão intimamente ligadas à celebração de um casamento. Optei por trabalhar com a narrativa mais comum e recorrente, apontada, inclusive, pelo trabalho de Luciana Chianca (2013a).

${ }^{21}$ A problemática da atribuição de paternidade consiste num debate clássico na antropologia, abrangendo de Malinowski (1983) a Strathern (1995) e reaparecendo em inúmeros trabalhos antropológicos. Cabe aqui mencionar que essa temática foi recuperada por Edmund Leach (2001) ao problematizar o 
um drama estético referendado em um drama social de ordem moral, um tabu que ainda assombra (embora com menor vigor) as sociedades ocidentais contemporâneas calcadas em valores cristãos: a existência de um vínculo sexual sem o estabelecimento de vínculos de parentesco, o que denota maior autonomia feminina quanto aos usos do corpo e uma ameaçadora perda de controle da sexualidade das mulheres por parte dos homens de suas famílias. A celebração do matrimônio surge como ação reparadora do drama instaurado, resultando na inserção de homens e mulheres em um sistema de relações de parentesco. Se, em alguns casos, o ritual possui uma função de reintegração - que é uma das fases do drama social - sugiro que os certames juninos são dramas estéticos concebidos como mecanismos rituais de reintegração dos sujeitos à ordem generificada das coisas.

Inspirado na combinação de minhas leituras de Turner (1982; 2005a; 2005b; 2008) e Butler (2003; 2010a; 2010b) encontro chaves interpretativas para sugerir que as narrativas juninas evocam, performaticamente, o desejo que os sujeitos possuem por uma definição que os posicione na estrutura social do ponto de vista das relações de gênero e sexualidade: ou serão alocados no âmbito da estrutura, como homens e mulheres que se adequam às normas de inteligibilidade dos gêneros $e$ da heterossexualidade compulsória, ou ocuparão o âmbito da antiestrutura, constituindo uma communitas com sujeitos permanentemente liminares, inadmissíveis no patamar estrutural e relegados ao plano da abjeção, que integram zonas ilegítimas do gênero, da sexualidade e das relações de parentesco.

Mas seria possível analisar o drama estético do casamento junino a partir de uma interpretação exegética de seus símbolos rituais? Turner (2005a) reivindica a multivocalidade e a polissemia dos símbolos rituais, afirmando que são definidos por diferentes

conceito de paternidade sociológica sugerido por Malinowski (1983). Para uma análise crítica sobre a obra de Leach $(1996 ; 2001)$ e sua atenção à dimensão do desequilibrio social, à ideia de padrão estrutural $e$ ao conceito de paternidade sociológica, ver Noleto (2012). 
níveis de significado divididos em dois polos principais: oréctico/sensorial e normativo/ideológico. Depreendo que as danças juninas de modo geral apresentam alguns elementos que podem ser interpretados como símbolos rituais, a saber: a fogueira, as bandeiras de santo, os mastro (paus) dos santos, os movimentos corporais empreendidos por damas e cavalheiros e, por fim os elementos contidos nos trajes juninos como, por exemplo, os chapéus dos cavalheiros e as saias e os adereços de cabeça das damas. Todos esses elementos estão relacionados aos polos sensoriais e normativos evocados pelos símbolos, ressaltando, no plano oréctico, a sexualidade humana, e, no plano ideológico, o sistema de parentesco. ${ }^{22}$

Dito isso, estabeleço o seguinte quadro de relações: ${ }^{23}$

\begin{tabular}{|l|l|l|}
\hline \multicolumn{1}{|c|}{ Símbolo Ritual } & \multicolumn{1}{|c|}{$\begin{array}{c}\text { Polo Normativo/ } \\
\text { Ideológico }\end{array}$} & Polo Oréctico/ Sensorial \\
\hline Fogueira & $\begin{array}{l}\text { Domesticação da natureza, } \\
\text { domínio social do fogo }\end{array}$ & Consumação sexual \\
\hline $\begin{array}{l}\text { Bandeiras/ } \\
\text { Estandartes dos } \\
\text { santos }\end{array}$ & $\begin{array}{l}\text { Presença oficial da Igreja } \\
\text { Católica }\end{array}$ & $\begin{array}{l}\text { Maleabilidade; } \\
\text { movimento do corpo } \\
\text { dessacralizado pela } \\
\text { dança de caráter } \\
\text { sexual. }\end{array}$ \\
\hline $\begin{array}{l}\text { Movimento dos } \\
\text { cavalheiros } \\
\text { (braços e } \\
\text { pernas) }\end{array}$ & $\begin{array}{l}\text { Idealização normativa da } \\
\text { força de trabalho }\end{array}$ & $\begin{array}{l}\text { Masculinidade, força } \\
\text { física, disponibilidade } \\
\text { sexual. }\end{array}$ \\
\hline
\end{tabular}

${ }^{22}$ Comentando a obra de Turner, Cavalcanti (2012:119) conclui que "símbolos, para o autor, serão sempre objetos concretos que, situados entre outros símbolos, funcionam plenamente no contexto ritual. O ritual é, a um só tempo, um contexto sociocultural e situacional característico. Nesse ambiente, impregnado de crenças e valores, os símbolos exercem sua eficácia plena como articuladores de percepções e de classificações, tornando-se fatores capazes de impelir $e$ organizar a ação e a experiência humanas e de revelar os temas culturais subjacentes".

${ }^{23}$ Devido às limitações de espaço que tenho para concluir este texto, não apresentarei uma análise mais discursiva e textual sobre esses símbolos rituais, optando pela apresentação sintética deste quadro. 


\begin{tabular}{|c|c|c|}
\hline Símbolo Ritual & $\begin{array}{l}\text { Polo Normativo/ } \\
\text { Ideológico }\end{array}$ & Polo Oréctico/ Sensorial \\
\hline $\begin{array}{l}\text { Movimento das } \\
\text { damas (quadris, } \\
\text { saias e pernas) }\end{array}$ & $\begin{array}{l}\text { Reforço normativo da } \\
\text { "feminilidade" como } \\
\text { performance }\end{array}$ & $\begin{array}{l}\text { Movimento de suas } \\
\text { sexualidades, } \\
\text { disponibilidade sexual } \\
\text { condicionada ao } \\
\text { casamento }\end{array}$ \\
\hline $\begin{array}{l}\text { Chapéus e } \\
\text { calças dos } \\
\text { cavalheiros }\end{array}$ & $\begin{array}{l}\text { Racionalidade } \\
\text { "masculina"; inserção do } \\
\text { homem na esfera pública }\end{array}$ & $\begin{array}{l}\text { Esforço físico sob o sol; } \\
\text { dimensão sexual da } \\
\text { identidade "masculina" }\end{array}$ \\
\hline $\begin{array}{l}\text { Adereços de } \\
\text { cabeça e saias } \\
\text { das damas }\end{array}$ & $\begin{array}{l}\text { Futilidade "feminina"; } \\
\text { "feminilidade" hegemônica } \\
\text { nas esferas pública e } \\
\text { privada }\end{array}$ & $\begin{array}{l}\text { Sensualidade dos } \\
\text { cabelos; dimensão } \\
\text { sexual da identidade } \\
\text { "feminina" }\end{array}$ \\
\hline
\end{tabular}

Aproximando o debate para os termos mais apropriados aos estudos de gênero e sexualidade, pretendo estabelecer um diálogo mais explícito com as contribuições teóricas de Michel Foucault (1988:117) quando postula a existência de dois dispositivos que regem e controlam a sexualidade dos sujeitos no campo político, a saber, o dispositivo da aliança e o da sexualidade. Infiro que as quadrilhas - referidas agora não como grupos coreográficos, mas como típicas danças juninas - condensam e atualizam as concepções vigentes em torno desses dois dispositivos foucaultianos. Conjugados em simultaneidade, os dispositivos da aliança e da sexualidade referem-se, respectivamente, aos patamares normativos e sensoriais prescritos discursivamente para reger e controlar a sexualidade dos sujeitos no campo político. Através dos polos oréctico e ideológico de seus símbolos rituais, as quadrilhas mais "tradicionais", que conservam a celebração de um matrimônio como centro dramático de suas performances, $\mathrm{o}$ fazem de uma maneira que colocam em evidência o convívio nem sempre harmonioso entre desejo sexual e sistema de parentesco, conduta e norma, natureza e cultura, indivíduo e sociedade. As quadrilhas juninas performatizam o conflito dos sujeitos tanto com o dispositivo da aliança, caracterizado pelo controle normativo do desejo sexual, quanto com o dispositivo da sexualidade, marcado 
pelo controle discursivo, microfísico e polimorfo dos corpos no âmbito da fruição de prazeres.

\section{Parentesco em questão}

Mas o que dizer das quadrilhas nas quais o casamento não é realizado? Como pensar no contexto junino a partir de um grande protagonismo de sujeitos que desestabilizam a matriz cultural da inteligibilidade dos gêneros? Quais as provocações empreendidas no âmbito quadrilheiro por homossexuais, travestis, transexuais e transgêneros quando põem em performance as temáticas do amor, da sexualidade e do parentesco? Como já dito, a realização do matrimônio não consiste em um núcleo dramático central de (e para) onde irradia toda a performance nas quadrilhas de Belém. A existência do casamento é dispensável, não há obrigatoriedade de sua realização performática. Assim, o casamento pode ser realizado, ignorado ou mesmo subentendido.

$\mathrm{Na}$ grande maioria das quadrilhas de Belém, os brincantes dançam passos que são, aparentemente, desconexos. $\mathrm{O}$ encadeamento da dança não faz referência direta a uma narrativa linear, pois as coreografias privilegiam um formato mais abstrato, que valoriza o efeito estético dos movimentos dos quadrilheiros ao se deslocarem pelo espaço. As quadrilhas de Belém são, portanto, mais sugestivas do que literais. Sem dúvida, a presença dos passos "tradicionais" juninos é uma marca indelével em todas as coreografias. Assim, é possível verificar passos como "caminho da roça", "grande roda", "túnel", "serrote", "coroa de damas", "coroa de cavalheiros" dentre outros. ${ }^{24}$ Tais movimentos são colocados em cena como memórias coreográficas de uma "tradição" à qual se possui algum tipo de filiação. Os movimentos sugerem a cumplicidade entre damas e cavalheiros e, mais do que isso, encenam o cortejo afetivo, o desejo sexual e a possibilidade iminente do casamento. Não obstante, a sequência coreográfica

\footnotetext{
${ }^{24}$ Eleonora Leal (2004:53-64) realizou um estudo sobre o que denominou como "evolução" das coreografias juninas em Belém.
} 
não está enredada numa narrativa central, não há uma intercalação precisa entre instantes de dança $e$ intervenções estritamente mais teatrais como, por exemplo, a contagem de uma história por meio de diálogos que interrompem o fluxo coreográfico dançado. Nas quadrilhas de Belém, há mais coreografia do que dramaturgia propriamente dita, sendo $\mathrm{o}$ casamento e a narrativa que o antecede inteiramente facultativos.

Como visto, as ideias de drama social e estético consistem em eficientes ferramentas analíticas para colocar em debate as narrativas juninas pautadas no matrimônio. Tal enredo construído em termos de ruptura, crise, ação reparadora $e$ reintegração/cisão - pode ser percebido em inúmeras quadrilhas brasileiras que elegem o casamento como centro dramático propulsor. Isso inclui também as quadrilhas de Belém que, por decisão facultativa, podem investir em algum enredo cujo foco narrativo esteja relacionado ao casamento. Não obstante, as noções de drama social e estético tornam-se inadequadas para falar da grande maioria das quadrilhas de Belém, tendo em vista que sua construção coreográfica adota uma perspectiva mais abstrata e fragmentada. É nesse sentido que pretendo acompanhar as críticas de Schechner (2012:76) aos limites da teoria do drama social em Turner. Para o autor,

a teoria reduz e nivela os eventos. Detalhes precisos, altos e baixos, nuances e diferenças, que fazem a análise cultural interessante e iluminada, são pressionados a uma uniformidade [...] Turner pôde transformar os conflitos do mundo em dramas de estilo ocidental. Talvez o mundo de hoje, de terrorismo, guerrilha, guerras civis prolongadas $e$ espionagem econômica seja melhor modelado pela arte da performance (Schechner, 2012:76).

Em termos de gêneros estéticos usados como metáfora para a compreensão de questões sociais, sugiro que as quadrilhas de Belém, com suas narrativas abstratas e fragmentadas sem um núcleo dramático propulsor, seriam melhor apreendidas pelo conceito de performance, considerado em sua acepção estrita de 
formato estético. ${ }^{25}$ Se o matrimônio é o centro dramático de muitas quadrilhas, constituindo-se como elemento que vincula tais grupos a uma ideia de "tradição" quadrilheira, sugiro que, dessa perspectiva, as quadrilhas de Belém sejam acéfalas, pois não encenam explicitamente o drama social e estético do casamento. A ênfase dramática das quadrilhas de Belém não recai sobre uma noiva desamparada e frágil, mas em três categorias de misses (Caipira, Mulata e Simpatia), que engendram diferentes tipos de "feminilidade" $e$, de acordo com a análise exegética que proponho, não estão disponíveis para serem colocadas em um sistema de relações de parentesco que produz um sistema de sexo/gênero. Inspiro-me na tradição antropológica dos estudos de parentesco - referindo-me especialmente às contribuições teóricas de Lévi-Strauss (2012), às críticas feitas a ele por Gayle Rubin (1993) e às reflexões de Adriana Piscitelli (1998), John Borneman (1996; 2005) David Schneider (1997), Marilyn Strathern (1997) e Miriam Grossi (2003) - para problematizar a participação de brincantes homossexuais, travestis, transexuais e transgêneros no âmbito quadrilheiro, complexificando a performance do parentesco que está em jogo nas quadrilhas juninas.

Lévi-Strauss (2012) é convincente ao afirmar que a proibição do incesto é um marco na passagem entre os domínios da natureza e da cultura. Dessa forma, postula a ideia de que "a proibição do incesto está ao mesmo tempo no limiar da cultura, na cultura, e em certo sentido [...], é a própria cultura" (LéviStrauss, 2012:49). Nessa perspectiva, é o matrimônio, circunscrito

\footnotetext{
${ }^{25}$ A esse respeito é inevitável citar Guillermo Gómez-Peña (2013), que, preocupado em problematizar a definição própria da performance como gênero estético, fala da complexidade para definir o campo de atuação dos performeros, pois não são exatamente atores, poetas, jornalistas, comentaristas, ativistas, artistas plásticos, designers etc., mas situam-se num entre-lugar dessas categorias, ocupam lugares não ocupados e intersticiais. O autor diz: "Em suma, nós somos o que os outros não são, dizemos o que os outros não dizem, $e$ ocupamos os espaços culturais que, em geral, são ignorados ou desprezados. Por isso, nossas numerosas comunidades estão constituídas por refugiados estéticos, políticos, étnicos e de gênero" (Gómez-Peña, 2013:444).
} 
pelo tabu do incesto, que favorece o estabelecimento de alianças entre grupos sociais distintos por regras culturais específicas. Assim, "todo casamento é, pois, o encontro dramático entre a natureza e a cultura, a aliança e o parentesco" (Lévi-Strauss, 2012:533). No entanto, para Lévi-Strauss, o sistema de parentesco é instituído a partir do dispositivo de "troca de mulheres", que, aliado à proibição do incesto, marca o próprio advento da cultura. Em crítica feita a esse autor, Rubin considerou que
a "troca das mulheres" não é uma definição de cultura, nem um sistema em si mesmo e por si mesmo. [...] a "troca das mulheres" é uma abreviação para expressar que as relações sociais de um sistema de parentesco especificam que os homens têm certos direitos sobre suas parentes $e$ que as mulheres não têm os mesmos direitos sobre si mesmas e sobre seus parentes do sexo masculino. Neste sentido, a "troca das mulheres" é uma percepção profunda de um sistema no qual as mulheres não têm direitos plenos sobre si próprias. A troca de mulheres torna-se uma ofuscação, se ela for vista como uma necessidade cultural $e$ quando é usada como um simples instrumento através do qual uma análise de um sistema cultural de parentesco é abordado (Rubin, 1993:10-11).

Para além de avaliar criticamente o conceito de "troca de mulheres", Rubin (1993:12) reconheceu no sistema de parentesco descrito por Lévi-Strauss a própria fonte cultural da heterossexualidade compulsória ao demonstrar que "os indivíduos são gerados a fim de garantir o casamento. Lévi-Strauss chega perigosamente perto de dizer que a heterossexualidade é um processo instituído". A autora continua o raciocínio afirmando que "os sistemas de parentesco não apenas encorajam a heterossexualidade em detrimento da homossexualidade. Em primeiro lugar, formas específicas de heterossexualidade podem ser requeridas" (Rubin, 1993:12). ${ }^{26} \mathrm{O}$ fato é que essa discussão

\footnotetext{
${ }^{26}$ Piscitelli (1998:310), em uma importante revisão bibliográfica acerca da temática do parentesco sob a ótica feminista, pontua que Rubin não rompe com
} 
antropológica em torno do parentesco estimula a reflexão sobre meu próprio campo de pesquisa, pois, de modo implícito ou explícito, o casamento, a sexualidade e os vínculos afetivos estão sendo representados $e$ reconfigurados pela performance coreografada de sujeitos da feminilidade que borram os limites da heterossexualidade e da díade damas/ cavalheiros.

Se parece renovador o protagonismo de alguns desses sujeitos da feminilidade no contexto junino, encenando relações afetivossexuais que desafiam a heterossexualidade $e$ a divisão binária dos gêneros, sugiro que isso se deve à própria emergência contemporânea de novas identidades sexuais que demandam a legitimação de conjugalidades que extrapolam a heterossexualidade na esfera social. ${ }^{27} \mathrm{O}$ grande obstáculo a ser transposto após um processo de legitimação de conjugalidades não heterossexuais é o fato de que "a esfera da aliança íntima legítima é estabelecida graças à produção e à intensificação de zonas de ilegitimidade" (Butler, 2003:226). Ou seja, o reconhecimento da legitimidade de certas ligações de parentesco por aliança entre pessoas não heterossexuais cria, por oposição, algumas zonas ilegítimas do gênero, da sexualidade e dos vínculos conjugais. Como solução ao impasse, o ideal seria "criar uma estrutura que permite o reconhecimento de uma proliferação de formas de expressão sexual e intimidade, bem como argumentos para a sua legitimação pública" (Borneman, 1996:231).

Diante disso, quero trazer a discussão para o âmbito de minha pesquisa, problematizando a participação de sujeitos da

a concepção estruturalista de Lévi-Strauss, "pensa em termos de universais e opera com uma série de dualismos - sexo/gênero, natureza/cultura -, que se tornarão alvo das críticas feministas posteriores".

${ }^{27}$ Sobre esse aspecto, Miriam Grossi aborda as demandas homossexuais em torno da conjugalidade, postulando que "se o reconhecimento da homossexualidade se fez particularmente pela sexualidade, a emergência no final da década de 90, do reconhecimento da conjugalidade é um fato novo na construção das identidades homossexuais, marcadas nas décadas de 70 e 80 pela liberalização sexual que implicava a existência de múltiplos parceiros sexuais" (Grossi, 2003:266). 
feminilidade no contexto junino e suas implicações para o debate sobre parentesco. Como demonstrado, a narrativa quadrilheira está estruturada a partir de personagens generificados, a saber, marcadores, misses, cavalheiros e damas. Tais personagens, como argumentei até aqui, consistem em elementos estruturais constitutivos do drama social e estético encenados pelas quadrilhas. Não obstante, há elementos estruturalmente arredios que, do ponto de vista das concepções binárias e estanques do gênero e da sexualidade, desestabilizam, no plano estético, a divisão coreográfica binária entre damas e cavalheiros e, no plano simbólico/social, as concepções "tradicionais" sobre conjugalidade heterossexual. Esses elementos estruturalmente arredios são, justamente, todos aqueles sujeitos da feminilidade marcados por um autorreconhecimento não binário de suas identidades sexuais e de gênero. Essas pessoas ocupam os mais diversos cargos em suas respectivas quadrilhas. No entanto, neste momento, para falar acerca de casamento e parentesco, quero considerar apenas a díade estrutural dama/cavalheiro com seus respectivos equivalentes antiestruturais damas mix/cavalheiros "gays" ${ }^{28}$ Ainda que nem todas as quadrilhas de Belém tenham no matrimônio um núcleo dramático central, há um consenso de que as relações performáticas entre os brincantes pressupõem a iminência de contatos sexuais e envolvimentos afetivos, tornando a celebração de um casamento - ainda que não seja realizada no espaço cênico - uma possibilidade que pode ou não ser concretizada. De todo modo, o casamento está à espreita, como uma expectativa.

Pretendo com isso dizer que, do ponto de vista das damas mix ou dos cavalheiros que não mantêm padrões hegemônicos de "masculinidade" e comportamentos heterossexuais, sua presença no interior das quadrilhas sugere a configuração possível de um sistema de parentesco desvinculado da convenção "tradicional"

\footnotetext{
${ }^{28}$ A designação "gay" é usada em sentido êmico por meu interlocutores para fazer referência a todo e qualquer sujeito que divirja da norma heterossexual ou da oposição binária homem/mulher. Nessa categoria êmica podem ser abarcados sujeitos gays, travestis, transexuais e transgênero. Por isso, o uso de aspas nesse caso.
} 
da heterossexualidade e das constituições de descendência familiar baseadas em critérios mais estritos de consanguinidade. Isso reconfigura os modelos vigentes de conjugalidade $e$ constituição familiar, tendo em vista que até hoje não é possível garantir a reprodução da espécie por vias biológicas entre dois homens ou entre um homem e uma travesti ou ainda entre um homem e uma mulher transexual, para citar alguns exemplos.

Com relação à temática do parentesco, Françoise Héritier (2000) contrapõe, de modo provocador, as novas formas de procriação assistida - advindas dos avanços tecnológicos da ciência no século XX - a certas instituições sociais, verificadas em sociedades tribais, usadas para enfrentar determinados problemas relativos à reprodução humana (a esterilidade, por exemplo). Somente a partir do fato biológico (o nascimento de uma criança) serão criadas ou aplicadas regras de filiação que circunscrevem o próprio sistema de parentesco. Os ricos e inúmeros exemplos etnográficos elencados pela autora demonstram formas alternativas de assegurar a paternidade ou maternidade em muitos grupos étnicos. Embora não esteja tratando de relações exatamente homossexuais, o argumento de Héritier demonstra como, por exemplo, duas mulheres, mantendo uma aliança formal de casamento, podem estabelecer relações de pater e mater com uma criança fecundada por outrem. Os dados etnográficos mobilizados a partir de sociedades tribais se contrapóem às formas contemporâneas (e ocidentais) de reprodução assistida, que, como se fossem uma novidade do ponto de vista sócio-antropológico, permitiriam a formação de famílias não necessariamente compostas pela díade homem/mulher. Héritier demonstra como esses arranjos alternativos para garantir a procriação entre grupos sociais não é um fator social novo. Ao que me interessa para as problematizações aqui contidas, tal elemento burlaria a impossibilidade biológica de que dois homens, duas mulheres, um homem e uma travesti ou outras combinações de sujeitos pudessem ter e criar filhos. No caso de minha pesquisa, a presença de sujeitos da feminilidade nas quadrilhas de Belém sugere outras formas de produção e reprodução do parentesco. 
Meu ponto de discussão é o fato de que a performance quadrilheira em Belém faz referência a uma controvérsia contemporânea que está posta na cena pública: os debates sobre direitos sexuais, novas conjugalidades e constituições de modelos familiares. $^{29}$

Não obstante, a ausência ou a opacidade do casamento no plano performático de muitas quadrilhas de Belém acompanha a dinâmica social contemporânea da fluidez dos afetos, das experimentações sexuais, da menor estabilidade das relações e do relaxamento em torno da obrigatoriedade de um matrimônio vitalício. É por esse motivo que considero as noções de drama social e drama estético inadequadas para analisar esse contexto junino complexificado pelo protagonismo de sujeitos da feminilidade que escapam às definições binárias do gênero e da sexualidade. No caso em questão, o gênero estético mais adequado como metáfora de análise da quadra junina de Belém é propriamente a performance, tendo em vista o seu caráter mais fragmentado, fluido, abstrato e descontínuo como características intrínsecas de sua constituição como modalidade liminóide de

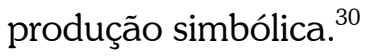

De todo modo, apesar de enfatizar a fluidez e a instabilidade das relações afetivossexuais, essa presença perturbadora de sujeitos da feminilidade na quadra junina de Belém tangencia igualmente as discussões contemporâneas acerca das novas possibilidades de contração de parentesco (por aliança) $e$ constituição de família através das reivindicações em torno do

\footnotetext{
${ }^{29}$ Sérgio Carrara (2015) elabora uma instigante provocação reflexiva na qual identifica possíveis transformações no dispositivo da sexualidade foucaultiano através da emergência dos direitos sexuais como um campo dos direitos humanos, criando um "novo" regime secular da sexualidade que está baseado na disputa jurídica, no campo político, relativa à concessão ou ao cerceamento de direitos a sujeitos sexuais específicos.

${ }^{30}$ Para o conceito de gêneros liminóides de produção simbólica, ver Turner (2012).
} 
casamento civil igualitário como um direito (Almeida, 2006). ${ }^{31}$ Schneider (1997) utiliza uma retórica do amor para afirmar que "a homossexualidade não é muito diferente da heterossexualidade no que se refere às concepções de parentesco e família. Casais gays e lésbicos são formados por pessoas que se amam. Eles formam uma unidade doméstica" (Schneider, 1997:270). Na avaliação de Strathern (1997:282), as configurações de parentesco são também uma questão estética, que rendem boas discussões teórico-analíticas, proporcionando a visão de que a heterossexualidade já esteve no centro do parentesco americano, mas, no contexto atual, a conjugalidade homossexual vem ganhando um protagonismo que coloca questões desafiadoras como, por exemplo, o desejo pela constituição de famílias com filhos. ${ }^{32}$

Todas essas questões estão em cena, subentendidas nas quadrilhas juninas nas quais a diversidade sexual e de gênero desestabiliza prescrições normativas binárias. Incialmente, coloquei em debate as quadrilhas que possuem no casamento um centro dramático fundante da narrativa junina, podendo ser compreendidas a partir do enfoque da teoria do drama social. Nesse caso, com base no entendimento de que dramas sociais $e$ dramas estéticos afetam-se mutuamente, sugeri e tentei demonstrar que as quadrilhas seriam um drama estético que faz referência ao drama social de atribuição da paternidade e de perpetuação dos sistemas de parentesco. Tal drama social é de fundamental importância para que os grupos sociais pensem sobre si mesmos e sobre os próprios mecanismos garantidores de sua perenidade social. $\mathrm{O}$ matrimônio, nesse caso, é encenado em algumas quadrilhas de Belém, mas não consiste em um acontecimento dramático central. Assim, as quadrilhas de Belém

\footnotetext{
${ }^{31}$ Acerca das discussões em torno do casamento civil igualitário no Brasil e sobre a conflituosa inserção de moralidades religiosas em certos debates públicos sobre direitos sexuais, ver Noleto (2016).

${ }^{32}$ As referências aos textos de Schneider (1997) e Strathern (1997) foram feitas a partir de livres traduções minhas.
} 
seriam acéfalas e constituídas por uma formação coreográfica mais abstrata, fragmentada e descontínua, o que me estimulou a perceber que seriam melhor compreendidas pela metáfora do gênero estético da performance e não do drama social. $\mathrm{O}$ protagonismo dos sujeitos da feminilidade no interior desses grupos representa tanto a reivindicação por legitimação social $e$ garantias jurídicas relativas ao casamento civil igualitário quanto a fluidez $e$ a instabilidade que caracterizam os modos de experimentação contemporâneos acerca da vivência do amor, do desejo e da própria conjugalidade.

\section{Drama, performance, ritual $e$ festa}

Se observados em múltiplos planos, os folguedos juninos podem ser compreendidos por diversas perspectivas. Considerando, primeiramente, as quadrilhas em sua condição estética de dança, é possível entendê-las como performances ou dramas, tendo em vista que são representações corporais que se revestem de códigos próprios da arte, materializados em movimentos. Se o foco recai sobre os certames juninos de quadrilhas e/ou de misses, sugiro que podem ser compreendidos sob o modelo teórico do ritual, pois são constituídos pela estrutura repetitiva, formal, extraordinária e comunicativa própria dos rituais. ${ }^{33}$ Pensando nesse contexto etnográfico como folguedos juninos, depreendo que o conceito adequado para designá-los seria festa. ${ }^{34}$ Essas noções de performance, drama, ritual e festa, embora sensivelmente distintas, articulam-se entre si. Não as tomo

\footnotetext{
${ }^{33}$ Para importantes revisões bibliográficas sobre as teorias de ritual na história da antropologia, ver Peirano (2000; 2003; 2006).

${ }^{34}$ Léa Perez (2012) postula a ideia de que se deve passar da festa-fato para a festa-questão, isto é, apreender a festa como perspectiva de análise e não como um fato a ser descrito em termos teleológicos. Assim, a autora advoga que a festa é produtora (e não reprodutora!) da vida social. Considera que a festa é transocial e afirma que "na festa a coletividade pode experimentar, e experimenta, uma existência outra que a do real socializado, uma existência que é própria da festa" (Perez, 2012:39).
} 
de modo hierárquico, sugerindo que umas englobam as outras. Entendo que estão articuladas e informam, cada uma à sua maneira, formas diferentes de perceber o contexto etnográfico do São João. Entretanto, considero que, se há uma noção predominante nesta minha análise, ela se refere ao ritual, pois compartilho da ideia de que "os rituais aparentam ser fundamentais para a elaboração das diferenças de gênero e das relações entre papéis de gênero" (Gontijo, 2009:196).

Concordo ainda que esses contextos rituais, performáticos e festivos são especialmente interessantes para problematização de questões referentes às relações de gênero $e$ às vivências das sexualidades. Ao conectar, de maneira inovadora, teorias de ritual $e$ estudos de gênero e sexualidade no contexto do carnaval, Fabiano Gontijo (2009:30) conclui que

é assim que vemos a permissão e a difusão das
homossexualidades dentro de certos limites, em particular
no domínio do lazer e das festas e, de forma mais restrita
ainda, durante o carnaval, enquanto communitas, ao passo
que a heterossexualidade seria a estrutura.

É nesse sentido que procuro também encontrar nas teorias de ritual e performance ferramentas analíticas que proporcionem uma análise iluminadora das festas juninas no que diz respeito ao protagonismo de certos sujeitos da feminilidade nesse contexto. Minha intenção é contribuir para problematizar o lugar da sexualidade e do gênero no âmbito de produção da cultura popular no Brasil.

Contrapondo minha pesquisa à de Gontijo (2009), quero dizer que, por um lado, o carnaval pode ser compreendido como uma festa popular ligada, em primeiro plano, às ideias de desvínculo conjugal, permissividade sexual e abertura para as experiências dissidentes à heterossexualidade. Por outro lado, as festas juninas são, em primeira instância, referidas às noções de vínculos conjugais, restrições sexuais, família e relações de compadrio. Talvez essa ideia dicotômica valha apenas em 
primeira análise porque tanto o carnaval quanto as festas juninas são matizados por dimensões respectivamente conservadoras $e$ libertárias. No caso do carnaval, atualmente há uma configuração moral que, por exemplo, visa controlar a exposição dos corpos no contexto das escolas de samba. No caso das festas juninas, a participação de sujeitos da feminilidade borra as fronteiras convencionais entre damas e cavalheiros e, principalmente, entre hetero e homossexualidade, propondo novas formas de vivência dos prazeres e novos contornos para os vínculos afetivos.

A partir de meu trabalho de campo, observei que, por um lado, os homossexuais e pessoas "trans" desestabilizam, no plano social, o pressuposto heterossexual contido nos concursos juninos, compostos por "casais" ou "pares" que encenam uma suposta heterossexualidade inconteste entre "damas" e "cavalheiros" respectivamente os personagens "femininos" e "masculinos" de uma quadrilha. Mas, por outro lado, no plano performático, a heterossexualidade é reforçada como norma, visto que, visualmente, há a formação de um casal heterossexual. Quero com isso dizer que mesmo havendo sujeitos homossexuais $e$ "trans" nos concursos juninos de Belém, os regulamentos dos certames consideram como inadmissível, por exemplo, que uma quadrilha seja composta por pares de brincantes compostos por dois cavalheiros ou duas damas. Sugiro, então, que as quadrilhas juninas de Belém funcionam a partir de uma heterossexualidade e cisgeneridade coreográfica, isto é, uma configuração narrativa de dança que produz efeitos performativos de heterossexualidade $e$ cisgeneridade, mas que nem sempre é protagonizada por sujeitos heterossexuais e cisgêneros. Considero que, para entender os significados profundos de certos contextos festivos, rituais ou performáticos, é importante reter a ideia proposta por Schechner (2012) acerca das afetações mútuas entre dramas sociais $e$ estéticos. Nessa configuração, os dramas estéticos (em formato de performances artísticas) afetam e são afetados, produzem e são produzidos, constituem e são constituídos por dramas sociais. Tentei demonstrar aqui como as narrativas juninas possuem um potencial criativo para dramatizar certos dilemas sociais 
contemporâneos acerca das identidades de gênero e sexualidade. Nesse campo discursivo estão em debate conceitos normativos de maternidade e paternidade, a fruição dos prazeres, o controle sobre a sexualidade e os corpos dos sujeitos, as relações de parentesco e a monogamia como norma social.

\section{Referências bibliográficas}

ALEXEYEFF, Kalissa. Dancing from the heart: movement, gender, and Cook Island globalization. Honolulu, University of Hawai'i Press, 2009.

AlmEIDA, Miguel Vale de. O casamento entre pessoas do mesmo sexo. Sobre "gentes remotas e estranhas" numa "sociedade decente". Revista Crítica de Ciências Sociais (76), 2006, pp.17-31.

ANDERSON, Benedict. Comunidades imaginadas: reflexóes sobre a origem e difusão do nacionalismo. São Paulo, Companhia das Letras, 2008 [1983].

BEDERMAN, Gail. Manliness and civilization: race, gender and sexuality in the United States, 1880-1917. Chicago, University of Chicago Press, 1996.

BENTO, Berenice; Pelúcio, Larissa. Despatologização do gênero: a politização das identidades abjetas. Revista Estudos Feministas 20(2), 2012, pp.569-581.

BORNEMAN, John. Until death do us part: marriage/death in anthropological discourse. American Ethnologist, 23 (2), 1996, pp.215-235. . Marriage today. American Ethnologist, 32 (1), 2005, pp.30-33.

BRAH, Avtar. Diferença, diversidade, diferenciação. cadernos pagu, (26), Campinas-SP, Núcleo de Estudos de Gênero-Pagu/Unicamp, 2006, pp.329-376.

BuRKE, Peter. Cultura popular na Idade Moderna: Europa 1500 - 1800. São Paulo, Companhia das Letras, 2010 [1978].

BUTLER, Judith. O parentesco é sempre tido como heterossexual? cadernos pagu, (21), Campinas-SP, Núcleo de Estudos de GêneroPagu/Unicamp, 2003, pp.219-260. 
. Desdiagnosticando o gênero. Physys - Revista de Saúde Coletiva, 19 (1), 2009, pp.95-126.

. Problemas de gênero: feminismo e subversão da identidade. Rio de Janeiro, Civilização Brasileira, 2010a.

. Corpos que pesam: sobre os limites discursivos do "sexo". In: LOURO, Guacira (org.) O corpo educado: pedagogias da sexualidade. Belo Horizonte, Autêntica Editora, 2010b, pp.151-172.

CARRARA, Sérgio. Políticas e direitos sexuais no Brasil contemporâneo. Bagoas n 5, Natal-RN, 2010, pp.131-147.

- Moralidades, racionalidades e políticas sexuais no Brasil contemporâneo. Mana 21 (2), Museu Nacional, Rio de Janeiro, 2015, pp.323-345.

CAVAlCANTI, Maria Laura Viveiros de Castro. Drama social: notas sobre um tema de Victor Turner. Cadernos de Campo (16), 2007, pp.127137.

. Luzes e sombras no dia social: o símbolo ritual em Victor Turner. Horizontes Antropológicos 37(1), 2012, pp.103-131.

ChIANCA, Luciana. A festa do interior: São João, migração e nostalgia em Natal no século XX. Natal, Editora da UFRN, 2006.

. Devoção e diversão: expressões contemporâneas de festas e santos católicos. Anthropológicas 18(2), 2007a, pp.49-74.

. Quando o campo está na cidade: migração, identidade e festa. Sociedade e cultura 10(1), 2007b, pp.45-59.

. São João na cidade: ensaios e improvisos sobre a festa junina. João Pessoa, UFPB, 2013a.

. O auxílio luxuoso da sanfona: tradição, espetáculo e mídia nos concursos de quadrilhas juninas. Revista Observatório Itaú Cultural (14), 2013b, pp.89-100.

CUNHA, Manuela Carneiro da. "Cultura" e cultura: conhecimentos tradicionais e direitos intelectuais. In: Cultura com aspas $e$ outros ensaios. São Paulo, Cosac Naify, 2009, pp.311-373.

DAWSEY, John. Victor Turner e a antropologia da experiência. Cadernos de Campo (13), 2005, pp.163-176. 
. Schechner, teatro e antropologia. Cadernos de Campo (20), 2011, pp.207-211.

DAWSEY, John; Müller, Regina; Hikiji, Rose; Monteiro, Marianna. Tranças [apresentação]. In: __. (org.). Antropologia e performance: ensaios NAPEDRA. São Paulo, Terceiro Nome, 2013, pp.17-36.

ENKE, Anne Finn. The Education of Little Cis: Cisgender and the Discipline of Opposing Bodies. In: __ . (ed.) Transfeminist perspectives: in and beyond transgender and gender studies. Philadelphia, Pensilvania, Temple University Press, 2012, pp.60-77.

EvANs-Pritchard, Edward. A dança. In: Cavalcanti, Maria Laura (org). Ritual e performance: 4 estudos clássicos. Rio de Janeiro, 7Letras, pp. 21-38, 2014 [1928].

FACCHINI, Regina. Sopa de letrinhas? Movimento homossexual e produção de identidades coletivas nos anos 90 . Rio de Janeiro, Garamond, 2009.

FouCAULT, Michel. História da sexualidade I: a vontade de saber. Rio de Janeiro, Edições Graal, 1988 [1976].

GÓMEZ-PEÑA, Guillermo. Em defesa da arte da performance. In: Dawsey, John; Müller, Regina; Hikiji, Rose Satiko G.; Monteiro, Marianna (org.). Antropologia e performance: ensaios NAPEDRA. São Paulo, Terceiro Nome, 2013, pp.441-465,.

GonTIJO, Fabiano. O rei momo e o arco-íris: homossexualidade $e$ carnaval no Rio de Janeiro. Rio de Janeiro, Garamond, 2009.

GREEN, JAMES. Além do carnaval: a homossexualidade masculina no Brasil do século XX. São Paulo, Editora Unesp, 2000.

GROSSI, Miriam Pillar. Gênero e parentesco: famílias gays e lésbicas no Brasil. cadernos pagu, (21), Campinas-SP, Núcleo de Estudos de Gênero-Pagu/Unicamp, 2003, pp.261-280.

HÉRITIER, Françoise. A coxa de Júpiter: reflexões sobre novos modos de procriação. Revista Estudos Feministas 8 (1), 2000, pp.98-114. [1985]

HobSBAWM, Eric; RANGeR, Terence. A invenção das tradiçóes. Rio de Janeiro, Paz e Terra, 2012 [1983]. 
LEACH, Edmund. Sistemas políticos da Alta Birmânia. São Paulo, Edusp, 1996 [1954]. [1961].

Repensando a antropologia. São Paulo, Perspectiva, 2001

LEAL, Eleonora. Contando o tempo: a evolução coreográfica das quadrilhas juninas em Belém do Pará. Dissertação (Mestrado em Artes Cênicas), Universidade Federal da Bahia (UFBA), Salvador, 2004.

LÉVI-STRAuSS, Claude. As estruturas elementares do parentesco. Petrópolis, Vozes, 2012 [1949].

MALINOWSKI, Bronislaw. A vida sexual dos selvagens. Rio de Janeiro, Francisco Alves, 1983 [1929].

MCCLINTOCK, Anne. Couro imperial: raça, gênero e sexualidade no embate colonial. Campinas, Editora Unicamp, 2010 [1995].

MENEZES Neto, Hugo. O balancê no Arraial da Capital: quadrilha e tradição no São João do Recife. Dissertação (Mestrado em Antropologia), Universidade Federal de Pernambuco, Recife, 2008.

. Música e festa na perspectiva das quadrilhas juninas de Recife. Anthropológicas 26(1), 2015, pp.103-133.

MouTiNHO, Laura. 'Raça', sexualidade e gênero na construção da identidade nacional: uma comparação entre Brasil e África do Sul. cadernos pagu, (23), Campinas-SP, Núcleo de Estudos de GêneroPagu/Unicamp, 2004a, pp.55-88.

- Razão, 'cor' e desejo: uma análise comparativa sobre relacionamentos afetivo-sexuais 'inter-raciais' no Brasil e na África do Sul. São Paulo, Editora Unesp, 2004b.

Noleto, Rafael da Silva. Edmund Ronald Leach e a dimensão do desequilíbrio. Ponto Urbe (11), 2012, pp.01-13.

"Brilham estrelas de São João!": notas sobre os concursos de "Miss Caipira Gay" e "Miss Caipira Mix" em Belém (PA). Sexualidad, salud y sociedad - Revista latino-americana (18), 2014, pp.74-110.

- Comunidades sexualizadas: articulando raça, gênero e sexualidade na construção de nações. In: CANCELA, Cristina Donza; MoutinHO, Laura; SimÔES, Julio (org.) Raça, etnicidade, sexualidade 
e gênero em perspectiva comparada. São Paulo, Terceiro Nome, 2015, pp.121-141.

- O canto da laicidade: Daniela Mercury e o debate sobre casamento civil igualitário no Brasil. Religião e Sociedade 36 (2), 2016, pp. 136-160.

PEIRANO, Mariza. A análise antropológica dos rituais. Série antropologia (270), 2000, pp.01-28.

. Rituais ontem e hoje. Rio de Janeiro, Jorge Zahar Editor, 2003.

Temas ou teorias? $\mathrm{O}$ estatuto das noções de ritual $e$ performance. Campos 7(2), 2006, pp.9-16.

Perez, Léa. Festa para além da festa. In: Perez, Léa; AmARAL, Leila; MESQUITA, Wânia (org.). Festa como perspectiva e em perspectiva. Rio de Janeiro, Garamond, 2012, pp.21-42.

PISCITELLI, Adriana. Nas fronteiras do natural: gênero e parentesco. Revista Estudos Feministas 6 (2), 1998, pp.305-322. . Interseccionalidades, categorias de articulação e experiências de migrantes brasileiras. Sociedade e cultura 11(2), 2008, pp.263-274.

RUBIN, Gayle. O tráfico de mulheres: notas sobre a "economia política" do sexo. Recife, SOS Corpo, 1993, pp.02-32 [1975].

SCHECHNER, Richard. Performance theory. New York/London, Routledge, 1988.

. Pontos de contato entre o pensamento antropológico e teatral. Cadernos de Campo (20), 2011, pp.213-236.

. Ritual. In: LigiÉRO, Zeca (org.) Performance e antropologia de Richard Schechner. Rio de Janeiro, Mauad X, 2012, pp.49-89.

. "Pontos de contato" revisitados. In: DAWSEY, John; MÜLLER, Regina; HIKIJI, Rose Satiko G.; MONTEIRO, Marianna (org.). Antropologia e performance: ensaios NAPEDRA. São Paulo, Terceiro Nome, 2013, pp.37-65.

SCHNEIDER, David. The Power of Culture: Notes on Some Aspects of Gay and Lesbian Kinship in America Today. Cultural Anthropology 12 (2), 1997, pp.270-274. 
SILVA, Rubens Alves da. Entre "artes" e "ciências": a noção de performance e drama no campo das ciências sociais. Horizontes antropológicos 24(2), 2005, pp.35-65.

SiMÕES, Júlio; FACCHINI, Regina. Na trilha do arco-íris: do movimento homossexual ao LGBT. São Paulo, Fundação Perseu Abramo, 2009.

STOLKE, Verena. O enigma das interseções: classe, 'raça', sexo, sexualidade. A formação dos impérios transatlânticos do século XVI ao XIX. Revista Estudos feministas 14(1), 2006, pp.15-42 [2003].

STRATHERN, Marilyn. Necessidade de pais, necessidade de mães. Revista Estudos Feministas, 03(2), 1995, pp.303-329.

. Dear David... Cultural Anthropology 12 (2), 1997, pp.281-282.

TURNER, Victor. From ritual to theatre: the human seriousness of play. New York, PAJ Publications, 1982. 1987.

. The anthropology of performance. New York, Paj Publications,

. Floresta de símbolos: aspectos do ritual ndembu. Niterói, EdUFF, 2005a [1967].

- Dewey, Dilthey e drama: um ensaio em antropologia da experiência (primeira parte). Cadernos de Campo (13), 2005b, pp.177-185 [1986].

- Dramas, campos e metáforas: ação simbólica na sociedade humana. Niterói, EdUFF, 2008 [1974].

. Liminal ao liminóide: em brincadeira, fluxo e ritual. Um ensaio de simbologia comparativa. Mediaçóes 17(2), 2012, pp.214-257, [1982].

. O processo ritual: estrutura e antiestrutura. Petrópolis, Vozes, 2013 [1969].

VAN GENNEP, Arnold. Os ritos de passagem: estudo sistemático dos ritos da porta e da soleira, da hospitalidade, da adoção, gravidez e parto, nascimento, infância, puberdade, iniciação, ordenação, coroação, noivado, casamento, funerais, estaçóes etc. Petrópolis, Vozes, 2011 [1909]. 
Wagner, Roy. A invenção da cultura. Coleção Portátil (16). São Paulo, Cosac Naify, 2012 [1975].

ZEMP, Hugo. Para entrar na dança. In: CAMARGO, Giselle G. A. (org.). Antropologia da dança I. Florianópolis, Insular, 2013, pp.31-56 [1998]. 